\title{
Karakteristik Ibu Hamil Dengan Hiperemesis Gravidarum Di RSUD Pasar Rebo Jakarta Timur
}

(Characteristics of Pregnant Women with Hyperemesis Gravidarum in RSUD Pasar Rebo, Jakarta Timur)

\author{
Rini Damayanti ${ }^{1 *}$, Dea Adelia' ${ }^{1}$, Winnie Tunggal Mutika1 ${ }^{1}$, Ambariani $^{1}$ \\ ${ }^{1}$ Program Studi Kebidanan Universitas Gunadarma \\ *Koresponden Penulis : rdamayanti226@gmail.com
}

\begin{abstract}
ABSTRAK
Penelitian ini bertujuan untuk mengetahui karakteristik ibu hamil dengan hiperemesis gravidarum di RSUD Pasar Rebo Jakarta Timur tahun 2016-2018. Metode penelitian yang digunakan adalah studi deskriptif. Sampel dalam penelitian ini adalah $107 \mathrm{ibu}$ hamil hiperemesis gravidarum di Rumah Sakit Umum Daerah Pasar Rebo, Jakarta Timur pada tahun 2016-2018. Teknik pengambilan sampel menggunakan metode Exhaustive Sampling. Variabel penelitian antara lain: usia, paritas, pendidikan dan pekerjaan. Penelitian ini menggunakan data sekunder yang diperoleh dari rekam medik. Hasil penelitian menunjukan bahwa $87 \%$ ibu hamil dengan hiperemesis gravidarum berusia 20-35 tahun, 47\% primipara, 43\% berpendidikan dasar dan 53\% memiliki pekerjaan. Kesimpulan: karakteristik Ibu Hamil dengan Hiperemesis Gravidarum di RSUD Pasar Rebo Jakarta Timur tahun 2016-2018 yaitu: berusia 20-35 tahun, primipara, berpendidikan dasar dan memiliki pekerjaan.
\end{abstract}

Kata kunci: Hiperemesis gravidarum, kehamilan, primipara.

\section{ABSTRACT}

This study aims to determine the characteristics of pregnant women with hyperemesis gravidarum in Pasar Rebo East Jakarta Hospital 2016-2018. The research method used is a descriptive study. The sample in this study were 107 pregnant women with hyperemesis gravidarum at Pasar Rebo Regional General Hospital, East Jakarta in 2016-2018. Sampling technique with Exhaustive sampling. The variables in this study are age, parity, education and employment. We used secondary data from the medical record. The results showed that $87 \%$ of hyperemesis gravidarum are aged $20-35$ years, $47 \%$ primiparous, $43 \%$ have a basic education, and 53\% have a job. Conclusions: characteristics of Pregnant Women with Hyperemesis Gravidarum in Pasar Rebo Regional Hospital in East Jakarta in 2016-2018: aged 20-35 years, primiparous, basic education, and having a job.

Keywords: Hyperemesis gravidarum, pregnancy, primiparous. 


\section{PENDAHULUAN}

Kehamilan merupakan peristiwa yang alamiah, mulai dari terjadinya pembuahan (konsepsi) hingga proses pertumbuhan janin di dalam rahim. Proses kehamilan yang normal terjadi selama 40 minggu antara waktu menstruasi sampai proses kelahiran (38 minggu dari pembuahan). Pada trimester pertama ibu hamil akan mengalami banyak perubahan fisik dan psikologi, perubahan fisik yang dialami ibu diakibatkan oleh perubahan hormonal. Salah satu pengaruh dari perubahan hormonal adalah ibu akan mengalami mual dan muntah (morning sickness), perubahan hormonal ini akan berakhir sampai badan wanita tersebut beraptasi dengan peningkatan produksi hormonal. Apabila mual dan muntah tidak tertangani dengan baik dan keadaan ibu semakin parah, hal itu akan mengakibatkan terjadinya hyperemesis gravidarum (Andi Kasrida Dahlan, 2017).

Hyperemesis gravidarum merupakan suatu keadaan (biasanya pada hamil muda) dimana penderita mengalami mual muntah yang berlebihan, sedemikian rupa sehingga mengganggu aktivitas dan kesehatan penderita secara keseluruhan. Angka kejadian hyperemesis gravidarum semakin meningkat. Menurut World Health Organization (WHO) pada tahun 2013, jumlah kejadian hyperemesis gravidarum mencapai 12,5\% dari seluruh jumlah kehamilan di dunia. Kunjungan pemeriksaan ibu hamil di Indonesia diperoleh data ibu dengan hyperemesis gravidarum mencapai 14,8\% dari seluruh kehamilan (Word Health Organization, 2015).

Angka Kematian Ibu (AKI) merupakan salah satu indikator untuk mengetahui tingkat keberhasilan dari sistem pelayanan kesehatan, untuk mengetahui komplikasi penyebab meningkatnya angka kematian ibu dan kesakitan ibu hamil sampai proses persalinan dan kelahiran. Salah satu komplikasi yang dimaksud adalah hyperemesis gravidarum (Perempuan \& Anak, 2016).

Beberapa faktor penyebab kejadian hyperemesis gravidarum meliputi faktor predisposisi terdiri dari usia, paritas, pekerjaan, pendidikan, molahidatidosa dan kehamilan ganda, faktor organik seperti alergi, masuknya vilikorialis sirkulasi, perubahan metabolic akibat kehamilan dan resistensi ibu yang menurun, faktor psikologis seperti stress, dukungan suami, ketidaksiapan untuk hamil atau kehamilan ini adalah kehamilan yang belum diinginkan, kekhawatiran bayi yang dilahirkan tidak sesuai dengan keinginan seperti jenis kelamin yang diinginkan kedua pasangan (Warsuli dan Mona Suparwati dan Purbowati., 2016).

Tujuan umum penelitian ini adalah mengetahui karakteristik ibu hamil dengan hiperemesis gravidarum di RSUD Pasar Rebo, Jakarta Timur tahun 2016-2018.

\section{METODE PENELITIAN}

Desain studi yang digunakan dalam penelitian ini adalah studi deskriftif. Populasi penelitian ini adalah seluruh ibu hamil dengan hiperemesis gravidarum di Rumah Sakit wilayah Pasar Rebo. Sampel penelitian ini berjumlah 107 ibu hamil dengan hiperemesis gravidarum di Rumah Sakit Pasar Rebo, Jakarta Timur tahun 2016-2018. Penelitian ini dilakukan di Rumah Sakit Umum Daerah Pasar Rebo, Jakarta Timur, pada tanggal 28 Juni sampai 30 Juli 2019. Data dalam penelitian ini merupakan data sekunder yang diperoleh dari rekam medik periode 2016-2018 yang meliputi usia, paritas, pendidikan, dan pekerjaan. Pengolahan dan analisis data menggunakan program Microsoft Excel. Analisis data bersifat univariat. 
HASIL

Peneitian ini menggunakan data sekunder sebanyak 107 ibu hamil yang mengalami hyperemesis (hyperemesis gravidarum).

Tabel 1. Karakteristik Ibu Hamil dengan Hyperemesis Gravidarum di RSUD Pasar Rebo Jakarta Timur

\begin{tabular}{lcc}
\multicolumn{1}{c}{ Variabel } & N & \% \\
\hline Usia & 2 & 2 \\
$<20$ tahun & 93 & 87 \\
$20-35$ tahun & 12 & 11 \\
$>35$ tahun & & \\
Paritas & 50 & 47 \\
$\quad$ Primipara & 43 & 40 \\
Multipara & 14 & 13 \\
Grandemultipara & & \\
Pendidikan & 46 & 43 \\
Dasar (SD, SMP) & 37 & 35 \\
Menengah (SMA) & 24 & 22 \\
Tinggi (PT) & & 53 \\
Pekerjaan & 57 & 47 \\
$\quad$ Bekerja & 50 & \\
Tidak Bekerja &
\end{tabular}

Pada variabel usia, ibu hamil yang mengalami hiperemesis gravidarum yaitu sebanyak 93 ibu hamil (87\%) berusia 20 sampai 35 tahun. Pada variabel paritas, ibu hamil yang mengalami hiperemesis gravidarum yaitu sebanyak 50 ibu hamil (47\%) ibu hamil merupakan primipara. Pada variabel pendidikan, ibu hamil yang mengalami hiperemesis gravidarum yaitu terbanyak ada pada kelompok ibu hamil dengan pendidikan dasar yaitu 46 ibu hamil (43\%). Pada variabel pekerjaan, ibu hamil yang mengalami hiperemesis gravidarum yaitu terbanyak pada kelompok ibu hamil yang memiliki pekerjaan yaitu 57 ibu hamil (53\%).

\section{PEMBAHASAN}

Pada variabel usia, ibu hamil yang mengalami hiperemesis gravidarum yaitu sebanyak 93 ibu hamil (87\%) berusia 20 sampai 35 tahun. Usia 20-35 tahun merupakan usia reproduksi sehat karena alat-alat reproduksi bekerja secara maksimal sehingga mengurangi risiko terjadinya komplikasi kehamilan. Namun pada usia tersebut masih dapat terjadi Hiperemesis Gravidarum yang disebabkan oleh faktor lain, seperti faktor psikologis, dan faktor hormona (Wadud, 2013).

Umur ibu mempunyai pengaruh yang erat dengan perkembangan alat reproduksi. Hal ini berkaitan dengan keadaan fisiknya dari organ tubuh didalam menerima kehadiran dan mendukung perkembangan janin. Seorang wanita memasuki usia perkawinan atau mengakhiri fase tertentu dalam kehidupannya yaitu umur reproduksi. Umur reproduksi yang ideal bagi wanita untuk hamil dan melahirkan adalah 20-35 tahun, keadaan ini disebabkan karena pada umur kurang dari 20 tahun rahim dan panggul ibu belum berkembang dengan baik dan belum cukup dewasa untuk menjadi ibu sedangkan pada umur 35 tahun keatas elastisitas otot-otot panggul dan sekitarnya 
serta alat-alat reproduksi pada umumnya telah mengalami kemunduran sehingga dapat mempersulit persalinan dan selanjutnya dapat menyebabkan kematian pada ibu (Wadud, 2013).

Hasil penelitian didukung oleh penelitian Octaviani Wiwik tahun 2015 dengan judul "Faktor-faktor yang Berhubungan dengan Hiperemesis Gravidarum di Wilayah Kerja Puskesmas Padalarang" bahwa ibu hamil dengan hiperemesis gravidarum berusia 20 sampai 35 tahun merupakan responden terbanyak yaitu 84 responden $(80,8 \%)$ dari 104 responden.

Hasil penelitian yang tidak sejalan dengan teori dikarenakan pengambilan sampel untuk penelitia $n$ berdasarkan umur $<20$ tahun, 20-35 tahun dan $>35$ tahun tidak diambil dengan proporsi yang sama banyak yaitu sampel usia $<20$ tahun berjumlah 2 ibu hamil, usia 20-35 tahun berjumlah 93 ibu hamil dan usia $>35$ tahun berjumlah $12 \mathrm{ibu}$ hamil. Selain usia faktor lain yang dapat menyebabkan hiperemesis gravidarum seperti faktor stress dan psikologi.

Pada variabel paritas, ibu hamil yang mengalami hiperemesis gravidarum yaitu sebanyak 50 ibu hamil (47\%) ibu hamil merupakan primipara. Kejadian hiperemesis gravidarum lebih sering dialami oleh primigravida daripada multigravida (Wiknjosastro, 2009).

Hal ini berhubungan dengan tingkat stres dan usia ibu saat mengalami kehamilan pertama. Pada ibu primigravida faktor psikologik memegang peranan penting pada penyakit ini, takut terhadap kehamilan dan persalinan, takut terhadap tanggung jawab sebagai seorang ibu dapat menyebabkan konflik mental yang dapat memperberat mual dan muntah sebagai ekspresi tidak sadar terhadap ketidakinginan menjadi hamil atau sebagai pelarian kesukuran hidup (Wiknjosastro, 2009).

Faktor predisposisi yang ditemukan sebagai penyebab hiperemesis gravidarum adalah pada primigravida. Kejadian hiperemesis gravidarum lebih dialami oleh primigravida daripada multigravida. Hiperemesis gravidarum terjadi $60-80 \%$ pada primigravida dan 40-60\% pada multigravida (Wiknjosastro, 2009).

Hasil penelitian didukung oleh penelitian Ilma Nurfitri tahun 2014 dengan judul "Hubungan Paritas dengan Kejadian Hiperemesis Gravidarum pada Ibu Hamil di Puskesmas Purbaratu Kota Tasikmalaya" bahwa ibu hamil dengan hiperemesis gravidarum 22 responden (52,4\%) dari 42 responden merupakan primipara.

Hasil penelitian sesuai dengan teori yang menyatakan bahwa pada wanita yang belum pernah mengalami persalinan, banyak hambatan yang mungkin terjadi, terutama jika ditunjang dari usianya yang masih muda, pada masa hamil merasa sulit dengan keadaan yang baru (hamil), sehingga menganggap kehamilan sebagai suatu beban, padahal sebenarnya kehamilan adalah hal yang fisiologis. Kurang memperhatikan kehamilannya, termasuk kontrol kehamilan, sehingga dapat berdampak pada berbagai risiko, termasuk Hiperemesis Gravidarum.

Pada variabel pendidikan, ibu hamil yang mengalami hiperemesis gravidarum yaitu terbanyak ada pada kelompok ibu hamil dengan pendidikan dasar yaitu $46 \mathrm{ibu}$ hamil (43\%). Hasil penelitian tersebut sesuai dengan teori yang menjelaskan kejadian hiperemesis gravidarum pada ibu hamil lebih sering terjadi pada ibu hamil yang berpendidikan dasar. Secara teoritis ibu hamil yang berpendidikan lebih tinggi cenderung lebih memperhatikan kesehatan diri dan keluarganya (Winkjosastro, 2014). 
Pendidikan dapat mempengaruhi seseorang termasuk juga perilaku terhadap pola hidup dalam memotivasi untuk siap berperan serta dalam perubahan kesehatan. Rendahnya pendidikan seseorang makin sedikit keinginan untuk memanfaatkan pelayanan kesehatan, dan sebaliknya makin tingginya pendidikan seseorang, makin mudah untuk menerima informasi dan memanfaatkan pelayanan kesehatan yang ada (Sumijatun \& dkk, 2006).

Pendidikan merupakan faktor yang ada dalam individu seperti pengetahuan, sikap terhadap kesehatan serta tingkat pendidikan. Dimana untuk berprilaku kesehatan misalnya (pemeriksaan kesehatan bagi ibu hamil) diperlukan pengetahuan tentang manfaat periksa hamil, baik bagi kesehatan ibu sendiri maupun bagi janinnya (Sumijatun \& dkk, 2006).

Hasil penelitian didukung oleh penelitian Ilah Sursilah tahun 2014 dengan judul "Faktor-faktor yang Berhubungan dengan Hiperemesis Gravidarum di Puskesmas Astapada Cirebon" bahwa ibu hamil dengan hiperemesis gravidarum 45 responden (56,2\%) dari 80 berpendidikan dasar.

Pada variabel pekerjaan, ibu hamil yang mengalami hiperemesis gravidarum yaitu terbanyak pada kelompok ibu hamil yang memiliki pekerjaan yaitu $57 \mathrm{ibu}$ hamil (53\%). Pekerjaan adalah aktivitas yang dilakukan untuk menunjang kehidupannya dan kehidupan keluarganya, diukur berdasarkan jenis kegiatan yang dilakukan sehari-hari. Pekerjaan ibu yang berisiko rendah terhadap hiperemesis gravidarum antara ibu rumah tangga dan pekerja salon. Sedangkan pekerjaan yang berisiko tinggi antara lain adalah pelayan toko, pelayan departement store, pekerja kantor, karyawan pabrik, petani (Ismail, 2014).

Hal ini sesuai dengan pendapat Winkjosastro (Wiknjosastro, 2009) yang mengungkapkan bahwa faktor psikologi memegang peranan penting dalam penyakit ini, misalnya, kehilangan pekerjaan, beban pekerjaan yang berat, dapat menyebabkan konflik mental yang dapat memperberat mual dan muntah sebagai pelarian kesukaran hidup. Hal ini tidak jarang dapat diatasi dengan cara memberikan suasana baru, sehingga dapat mengurangi frekuensi muntah.

Hasil penelitian ini di dukung oleh penelitian Yusmiati tahun 2014 dengan judul "Hubungan Status Gravida, Pekerjaan dan Umur dengan Hiperemesis Gravidarum di Rumah Sakit Sentra Medika Cibinong" 56,2\% ibu hamil dengan hiperemesis gravidarum memiliki pekerjaan.

Pada umumnya, pekerjaan merupakan suatu kebutuhan dan pernyataan ini didukung oleh studi yang dilakukan oleh Steele, yang menyatakan bahwa satu dari tiga wanita dengan mual dan muntah mengalami stress dan perpecahan dalam keluarga, gangguan emosional, dan gangguan fungsi sosial. Hal ini terjadi pada wanita yang bekerja dimana hampir 50\% mengalami penurunan efisiensi kerja, dan 25\% membutuhkan waktu untuk istirahat kerja.

\section{KESIMPULAN DAN SARAN}

Berdasarkan hasil penelitian yang telah dilakukan, maka dapat disimpulkan ibu hamil dengan hiperemesis gravidarum di RSUD Pasar Rebo terbanyak berusia 20 sampai 35 tahun, merupakan primipara, pendidikan dasar dan bekerja. 
18 | Jurnal Kesmas Untika Luwuk: Public Health Journal. 11 (1): 13-18

Saran untuk peneliti selanjutnya dapat menganalisis lebih lanjut karakteritik ibu hamil dengan hiperemesis gravidarum atau menggambarkan karakteristik lainnya..

\section{UCAPAN TERIMA KASIH}

Ucapan terimakasih penulis sampaikan kepada pihak BRSD Pasar Rebo Jakarta Timur, khususnya pada instalasi rekam medic atas izin penggunaan data ibu hamil yang mengalami hiperemesis gravidarum.

\section{DAFTAR PUSTAKA}

Andi Kasrida Dahlan, A. S. U. (2017). Faktor Yang Berhubungan Dengan Pengetahuan Ibu Hamil Primigravida Dalam Pengenalan Tanda Bahaya Kehamilan. Voice of Midwifery, 7(9), 1-14. http://garuda.ristekbrin.go.id/documents/detail/763630

Ismail. (2014). Pengaruh Pekerjaan terhadap Mual Muntah dalam Kehamilan.

Perempuan, K. P., \& Anak, D. P. (2016). Kajian Partisipasi Organisasi Perempuan Dalam Menurunkan Angka Kematian Ibu Di Propinsi Jawa Barat. https://www.kemenpppa.go.id/lib/uploads/list/1ebac-kajian-partisipasiorganisasi-perempuan-dalam-menurunkan-angka-kematian-ibu.pdf

Sumijatun, \& dkk. (2006). Konsep Dasar Keperawatan Komunitas. Jakarta: EGC.

Wadud, M. A. (2013). Hubungan Umur Dan Pekerjaan Ibu Dengan Kejadian Hyperemesis Gravidarum Di Instalasi Kebidanan Rumah Sakit Muhammadiyah Kota Palembang Tahun 2012. Poltekkespalembang.

Warsuli dan Mona Suparwati dan Purbowati. (2016). Hubungan Primigravida Terhadap Kejadian Hiperemesis Gravidarum di Puskesmas Pringapus Kecamatan Pringapus Kabupaten Semarang Tahun 2016. https://docplayer.info/41401961-Hubunganprimigravida-terhadap-kejadian-hiperemesis-gravidarum-di-puskesmaspringapus-kecamatan-pringapus-kabupaten-semarang-tahun-2016.html

Wiknjosastro. (2009). Ilmu Kebidanan (4th ed.). Yayasan Bina Pustaka Sarwono Prawirohardjo.

Word Health Organization. (2015). Reduction of Maternal Mortality: a joint WHO/UNFPA/UNICEF/World Bank statement. https://apps.who.int/iris/handle/10665/42191 